\title{
Prevalence of Bovine Trypanosomosis and its Vectors in Selected Peasant Associations of Boloso Bombe Woreda, Southern Ethiopia
}

\author{
Wondimu Wodajo* \\ College of Veterinary Medicine, Haramaya University, Ethiopia.
}

*Corresponding Author: Wondimu Wodajo, College of Veterinary Medicine, Haramaya University, Ethiopia.Email: tinbetw@gmail.com

\begin{abstract}
The study was conducted from November 2010 to March 2011 in selected peasant associations of the Boloso Bombe Woreda of Southern Nation Nationalities and Peoples Regional States (SNNPRS) to determine the prevalence of bovine trypanosomosis and its vectors. Blood samples were collected from 246 randomly selected cattle of the study villages and evaluated through standard parasitological methods. The PCV value of each animal was also measured using hematocrit reader. Fourteen animals (5.69\%) were found to be infected with two trypanosome species. Most of infections were due to T.congolense (78.56\%) followed by T.vivax (21.44\%). There was no correlation between the peasant associations (PAs) and level of trypanosome infection ( $p>0.05)$. There was also no significant difference $(p>0.05)$ between sex and age of animals with regard to infection by trypanosome. However, significant difference was observed between trypanosome infection with body condition of the study animals $(p<0.05)$. The mean PCV value of parasitemic and aparasitemic animals was recorded as $22.36 \%$ and $28.42 \%$, respectively. Statistically, highly significant difference was observed between the trypanosomosis infection rate and the PCV-value of animals ( $p<0.05)$. In the two peasant associations, entomological survey was conducted using NGU trap and it indicated that G. pallidipes and G. fuscipes were the tsetse fly species caught in the study area along with other biting flies like tabanus and stomoxys. An overall apparent density of tsetse and other biting flies were 0.5 flies/trap/day and 12.58 flies/trap/day, respectively. Due to its impact on livestock production, attention should be given for the control and prevention of trypanosome infection rate and its vectors.
\end{abstract}

Keywords: Boloso Bombe, Trypanosomosis, Trypanosome, Prevalence, Tsetse flies

List of Abbreviations: AAU -Addis Ababa University, BCS - Body Condition Scores, CI - Confidence interval, DNA - Deoxyribonucleic Acid, ELISA - Enzyme Linked Immunosorbent Assay, FAO - Food and Agricultural Organization, IFA - Indirect Fluorescent Antibody, Pas - Peasant associations, PCR Polymerase Chain Reaction, PCV - Packed cell volume, SNNPRS - Southern Nation Nationalities and People Regional State, USA - United States of America, WOA - Woreda of Agriculture

\section{INTRODUCTION}

In Ethiopia, trypanosomosis is one of the major impediments to the livestock development and agricultural production in contributing negatively to the overall development in agriculture in particular and to food self reliance efforts of the nation in general (MoARD, 2004). In Ethiopia, trypanosomosis is one of the most important disease limiting livestock productivity and agricultural development due to its high prevalence in the most arable and fertile land of Southwest and Northwest part of the country following the greater river basins of Abay, Omo, Ghibe and Baro with a high potential for agricultural development (Abebe, 2005).

Trypanosomsis is a debilitating and often fatal disease of various domestic animals. It is caused by the protozoan parasite belonging to the family trypanosomatidae genus trypanosome, which inhabits the blood plasma, various body fluids and tissues of their hosts. Trypanosome is a single celled extracellular parasite that is transmitted cyclically by tsetse flies and some species mechanically by other biting flies, tabanus and stomoxys (Leak, 1999 and Urquhart et al., 1996). Trypanosomes are flagellated protozoan organisms that can produce a variety of disease of humans and animals, although many are non-pathogenic (Smith, 2009) and also they are wide spread and economically important disease in humans and animals (Dwight, 2003).

Although tsetse flies have existed in Ethiopia for a very long time, it has been noted by early 
explorer and traveler, who lost their transport animals in the fly challenge belts. In 1885, Danolds and Smith made the earliest record of "Gendi" (Nagana) in their transport animal which were crossing tsetse fly belts in southern Ethiopia (Maclennar, 1980). Later in 1895, Corti identified an insect collected in 1893 by captain Bottogo along the Walmal River which is the upper tributary of Shebelle River (Langridge, 1976). Brumgt in 1904 reported in the Ogaden (South West Ethiopia), one form of bovine trypanosomosis which was called "Alino" and which was readily transmitted by $G$. Longipennis (Langridge, 1976). In 1962, the cattle survey in southern Ethiopia by the livestock division, established the bovine trypanosomosis had become a major cattle disease. In the Omo valley, it was stated that the problem of trypanosomosis is the main cause of decline in the number of cattle and particularly draught oxen (Abebe \& Jobere, 1996). Five species of Glossina including Glossina morsitans submorsitans, $G$. pallidipes, $G$. tachnoides, G. $f$. fuscipes and G. longipennis have been recorded in Ethiopia (Abebe, 2005).

The life cycle of trypanosome is complex in both tsetse fly vector and the mammalian host; trypanosome undergoes a series of transformations into different forms (Seifert, 1996). Most tsetse transmission is cyclical and begins when blood from a trypanosome infected animals are ingested by the fly. Trypanosomes losses its surface coat, multiplies in the fly, then reacquire a surface coat and becomes infective. $T$. brucei species migrate from the gut to the proventriculus to the pharynx and eventually to the salivary glands; the cycle for T.congolense stops at the hypo pharynx and the salivary glands are not invaded; the entire cycle for T.vivax occurs in the proboscis. The animal infective form in tsetse salivary gland is referred as the metacyclic form. The life cycle in tsetse may be as short as one week with T.vivax or extend to a few weeks for T.brucei species (Taylor et al., 2007).

The most important trypanosome species affecting livestock in Ethiopia are Trypanosome congolense, T.vivax and T.brucei, in cattle, sheep and goat, T.evansi in camel and T.equiperdum in horses (Abebe, 2005). However, sleeping sickness might also have a considerable public health importance in the country. They are widely distributed throughout Africa and frequently encountered in infected animals. Morphologically, T.vivax is long slender monomorphic parasites with rounded posterior end, a terminal kinetoplast, and long free flagellum but no prominent undulating membrane. T.congolense is smallest of the pathogenic trypanosomes with small marginal kinetoplast, no free flagellum and no prominent undulating membrane (Radostitis et al., 2007). T.brucei is a polymorphic organism; the slender and intermediate forms having a long free flagellum posterior end, sub-terminal kinetoplast and prominent undulating membrane, the stumpy or short forms are broad with short or absent flagellum (Cynthia, 2005).

Among different diagnostic methods such as wet film, Giemsa staining methods, identification of the parasite in the buffycoat and zone of illumination are most accurate of all. The diseases show a variety of clinical manifestations, which are also common to other diseases. The diseases may run an acute, chronic or sub clinical course and fever can be observed which can be intermittent due to the variation of parasitaemia and if the animal survives, the diseases becomes chronic and development of anemia and emaciation (Radostitis et al., 2007).

Serological tests detect specific antibodies developed by the host against the infection or they demonstrate the presence of circulating parasitic antigens in the blood by the use of specific antibodies. Currently, a number of serological and molecular tests are used for the diagnosis of trypanosomosis, such as the indirect fluorescent antibody test (IFA), the indirect enzyme linked immunosorbent assay (ELISA) molecular tests, such as the polymerase chain reaction (PCR) and DNA-probes used for detecting the parasite DNA. Their use is more suitable for herd and area screening than for individual animal diagnosis. Tests for detecting circulating trypanosome species antigen in peripheral blood are becoming available for both individual and herd diagnosis, although their reliability remain unproven (Cynthia, 2005).

The clinical signs of trypanosomosis depend up on the species and strain of trypanosome, the vector and resistance of the affected breed of animals (Paris et al., 1979). Trypanosomois is usually a chronic disorder, the duration and symptoms of which vary with the animal hosts and pathogen (Itard, 1992). The basic clinical syndrome appears after an incubation period of 8-20 days, but may vary according to the host resistant and the type of trypanosome species involved (Radostitis et al., 2007). The extent of 
challenge by the disease is generally characterized by intermittent fever that lasts for a long period. Affected animals are dull, anorectic, apathetic, have a watery ocular discharge or lacrimation, and loss of condition, superficial lymph nodes become visibly swollen, anemia that revealed by pale mucous membrane, diarrhea occasionally occurs and some animals have edema of throat, estrus cycles become irregular, pregnant animals may abort, and semen quality progressively deteriorates. The animals become very emaciated and cachectic, thin, rough hair coated and falls out in patches on the back; and eyes sunken and die within 2-4 months or longer (Taylor et al., 2007). Fever and loss of condition are important parameters, which are routinely used for the tentative diagnosis of trypanosomosis in an area where the diseases is endemic and laboratory services are not available. However, clinical signs of tryanosomosis are not pathognomonic to the diseases and diagnosis is solely attained by parasitogical methods like dark ground phase contrast buffycoat technique which can be used under field condition to detect the presence or absence of trypanosomes (Murray et al., 1977).

Trypanosomiasis is number one disease problem in Boloso Bombe woreda. Treatment of cattle for trypanosomosis in the woreda is generally carried out without preliminary diagnosis. In the district, most of the drug treatments were administered inappropriately. During a survey carried out by Soddo Regional Veterinary Laboratory, farmers reported trypanosomosis to be the most important livestock development constraint in the study area. Therefore, controlling this economically important disease in this area could have enormous benefits to improve the livelihood of the rural population by boosting milk and meat production, improving the availability of draught oxen, and increasing surplus capital from the sale of livestock and livestock products.

It is this particular situation that justified cross sectional survey and assessment of prevalence of the disease and the present risk of tsetse and mechanical vectors transmitted trypanosomes in the study area.

Therefore, the objectives of the study were as follows:

* To determine the prevalence of bovine trypanosomosis in the selected peasant associations (PAs) of Boloso Bombe woreda.
* To identify tsetse flies and mechanical vectors involved in the study area.

\section{Materials ANd Methods}

\subsection{Study Area}

Boloso Bombe woreda is located at $390 \mathrm{~km}$ south from Addis Ababa, $190 \mathrm{~km}$ from Hawassa and $60 \mathrm{~km}$ from zonal town, Wolaita Soddo, southwest. The district covers a total of $21,852,747$ hectars. The altitude ranges from 700 (Omo river) to 2370 (Zaba mountain) meters above sea level. Agro ecologically, 75\% is lowland, $20 \%$ is midland and 5\% highland. The mean annual rainfall is $1,600 \mathrm{~mm}$ and mean annual temperature of the woreda ranges from a maximum of $24^{\circ} \mathrm{C}$ and minimum of $12^{\circ} \mathrm{C}$. The community grows crops which are early maturing, high yielding and drought resistant. Major crops growing in the area are maize, teff, ginger, sweet potato and inset (Bombe WOA, 2010).

Human population of Boloso Bombe woreda is 126,640. The woreda has livestock population of 67,576 cattle, 9,010 sheep, 11, 851 goats, 4, 344 donkeys, 166 mules, 38 horses and 42,663 poultry. Predominant species in the area is bovine and livestock management system is mixed farming system. The animals in the area mainly depend up on communal grazing fields as feed source and watering points are the ponds and rivers based up on their distribution (Bombe WOA, 2010).

\subsection{The Study Design}

A cross sectional study was conducted to assess the diseases prevalence, distribution and identification of tsetse fly and other mechanical vectors in the early dry seasons (November to December).

\subsection{Study Population}

The study populations were zebu cattle managed under small holder mixed crop-livestock farming system. During the study; the peasant associations, sex, age, body condition score and the PCV values were recorded. Cattle were grouped into two. Those under 1-3 years were categorized as young and those greater than 3 years of age were categorized as adult.

\subsection{Sampling Method and Sample Size Determination}

The sampling method applied in this study was simple random sampling. Totally, 246 cattle were sampled for estimation of bovine 
trypanosomosis prevalence. The sample size was calculated according to the following formula stated by Thrustfield (2005). The sample size was determined on the basis of an expected prevalence rate of $20 \%$ with a desired absolute precision of $5 \%$ at confidence level of 95\% based on previous study on Soddo Regional Veterinary Laboratory which reported prevalence of $15.77 \%$ to the study area (SRVL, 2004).

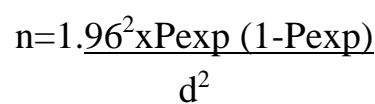

Where $n=$ required sample

$$
\mathrm{P}=\text { expected prevalence }
$$

$\mathrm{d}=$ desired absolute precision

\subsection{Study Methodology}

\subsubsection{Parasitological Survey}

Sample collection and parasitological examination was conducted on a total of 246 cattle for estimation of prevalence of bovine trypanosomosis in the study area. During sampling; age, sex, herd number, body condition and PCV-values were recorded. An altitude was stratified in to two; low land (<1500 m.a.s.1) and mid land (>1500 m.a.s.1).

Dark ground phase contrast buffycoat method was used to examine the trypanosomes in the blood of sampled animals. For trypanosome infection, paired blood samples were collected from marginal ear vein of each animal by using two hematorit capillary tubes that was filled up to $3 / 4$ of its length and sealed with bee wax at one end. The blood was centrifuged at $12,000 \mathrm{rpm}$ for 5 minutes. Then packed cell volume (PCV) was measured for determination of the level of anemia. After measuring the PCV values, the capillary tube cut using a diamond tipped pen 1 $\mathrm{mm}$ below the buffy coat to include the upper most layers of the red blood cells and $3 \mathrm{~mm}$ above to include the plasma and dispersed in to clean slide, mixed well and covered with a $22 \times 22 \mathrm{~mm}$ cover slip. Then the wet smear was examined for trypanosomes based on the type of movement observed in microscope field (Paris et al., 1982). Thin blood smears stained with Giemsa was examined with oil immersion microscope with $100 \times$ power of magnification for confirmation of trypanosome species on the basis of morphological characteristics. Consequently, the PCV of each sampling was estimated using a microhematocrit reader and trypanosome species was identified (Paris et al., 1982).

\subsubsection{Entomological Survey}

For the entomological study, tsetse flies and other mechanical vectors were collected by 12 NGU traps deployed in different positions of the study areas of Yogo village in Bedaye peasant association (6 traps) and Mechancho river gorge in the Ossie PA (6 traps). Acetone was used as a bait to attract flies. Traps were positioned at different grazing and watering points in which the animals and vectors were believed to have frequent contacts (FAO, 1992). Fly catch per trap per day (f/t/d) was determined to calculate the fly density and distribution. The species of tsetse flies was determined following standard procedures and other biting flies were identified according to their morphological characteristics such as size, color, wing venation structure, and proboscis at the genus level (FAO, 1992).

\subsection{Data Analysis}

Data collected from each study animal and laboratory analysis were coded and entered in to a Microsoft Excel Spreadsheet. All statistical analyses were performed using STATA-9 Software (stata corp.4905Lakeway drive college station, Texas 77845, USA). The prevalence of bovine trypanosomosis was calculated as the number of infected animals divided by the number of individuals' sampled $\times 100$. The association between prevalence of trypanosome infection and different study variables were analyzed by $\chi^{2}$ analysis. In all the analysis, the confidence level held at $95 \%$ and $p<0.05$ was required for significance. The density of fly population is calculated by dividing the number of flies caught by the number of traps deployed and the number of days of deployment, and as expressed as flies per traps per day (f/t/d).

\section{Results}

\subsection{Prevalence and Distribution of Trypanosome Species}

The result of the survey showed that out of the total cattle examined during the study period, 14 cattle were found to be positive for trypanosomosis with an overall prevalence of $5.69 \%$ (95\% CI $=2.78-8.60)$. On PA basis, Bedaye has prevalence of $10 \%$ followed by 9.43\%, 6\%, $1.93 \%$ and $0.00 \%$ in Ossie, Ajjora, Bombe and Ambe, respectively (Table 1). There was no significant correlation between trypanosome infection rates in these five peasant associations. The species of trypanosomes identified by Buffy coat technique and thin smear showed that $T$. congolense $11(78.56 \%)$ is 
Prevalence of Bovine Trypanosomosis and its Vectors in Selected Peasant Associations of Boloso Bombe Woreda, Southern Ethiopia

the most prevalent followed by $T$. vivax 3 $(21.44 \%)$ but there was not a case of mixed infection recorded in this study.

Table1. Prevalence of trypanosomosis in differeent peasant associations (PAs) of Boloso Bombe Woreda

\begin{tabular}{|l|c|c|c|}
\hline \multicolumn{1}{|c|}{ PA } & $\begin{array}{c}\text { No. } \\
\text { Examined }\end{array}$ & $\begin{array}{c}\text { Total } \\
\text { positive }\end{array}$ & $\begin{array}{c}\text { Prevalence } \\
(\boldsymbol{\%})\end{array}$ \\
\hline Bedaye & 50 & 5 & 10.00 \\
\hline Bombe & 51 & 1 & 1.96 \\
\hline Ajjora & 50 & 3 & 6.00 \\
\hline Ambe & 42 & 0 & 0.00 \\
\hline Ossie & 53 & 5 & 9.43 \\
\hline Total & $\mathbf{2 4 6}$ & $\mathbf{1 4}$ & $\mathbf{5 . 6 9}$ \\
\hline
\end{tabular}

$\chi^{2}: 6.978$, P-value: 0.137

\subsection{Prevalence of Trypanosomes Infection in Different Host Related Variables}

During the present study, from the total of 246 cattle examined, 142 were female and 104 of them were male animals. From female cattle examined, $4.23 \%$ were positive for trypanosomes infection while $7.69 \%$ of the male animals were found infected as shown in Table 2 below. There was no significant difference in the infection rate between male and female animals $(\mathrm{P}>0.05)$.

Body condition score was also evaluated in cattle which are living under similar environment and management system to see the impact of trypanosomosis in causing debilitation, which is clinical sign of trypanosomosis. Statistically, there was significant difference between animals of poor and good body condition scores (Table.2).

The prevalence of trypanosomosis was found to be $5.88 \%$ and $5.99 \%$ in young and adult age groups, respectively. Difference in infection rate among the different age groups were not statistically significant $(\mathrm{p}>0.05)$.

Table2. Prevalence of trypanosomosis in different sexes, age and body condition scores

\begin{tabular}{|c|l|c|c|c|c|c|}
\hline \multicolumn{2}{|c|}{ Variables } & Number examined & Number positive & Prevalence (\%) & $\boldsymbol{\chi}^{\mathbf{2}}$ & P-value \\
\hline \multirow{2}{*}{ Sex } & Female & 142 & 6 & 4.23 & 1.34 & 0.246 \\
\cline { 2 - 7 } & Male & 104 & 8 & 7.69 & 11.236 & 0.001 \\
\hline \multirow{2}{*}{ BCS } & Poor & 105 & 12 & 11.43 & & 0.42 \\
\cline { 2 - 5 } & Good & 141 & 2 & 5.88 & 0.009 & 0.925 \\
\hline \multirow{2}{*}{ Age } & Young & 85 & 5 & 5.59 & & \\
\cline { 2 - 6 } & Adult & 161 & 9 & & & \\
\hline
\end{tabular}

\subsection{Hematological Examination}

To assess the relationship between trypanosome infection and packed cell volume (PCV), PCV determination using hematocrit, and also the mean PCV of parasitemic and aparasitemic animals were calculated. The analysis showed that the mean PCV value for the parasitemic cattle was $22.36 \%$ which fall in the range of anemia whilst the mean PCV value of the aparasitemic cattle was $28.42 \%$. Cattle having $\mathrm{PCV} \leq 24 \%$ (anemic) were $18.87 \%$ whilst in the cattle having $\mathrm{PCV}>24 \%$ (non-anemic) were $2.07 \%$ as indicated in Table 3 . Out of total of 14 animals positive for trypanosomosis, 10 of them were found to be anemic and the rest 4 were with normal PCV value. The association of parasitemia with the case anemia was found to be significantly associated $(\mathrm{p}<0.05)$.

Table3. PCV evaluation for bovine trypanosomosis for parasitemic and aparasitemic animals

\begin{tabular}{|l|c|c|c|c|}
\hline Condition & No. of animals & Cattle with PCV( \%) $\leq \mathbf{2 4}$ & Cattle with PCV(\%) >24 & Mean PCV (\%) \\
\hline $\begin{array}{l}\text { Parasitemic } \\
\text { animals }\end{array}$ & 14 & $10(18.87 \%)$ & $4(2.07 \%)$ & 22.36 \\
\hline $\begin{array}{l}\text { Aparasitemic } \\
\text { animals }\end{array}$ & 232 & $43(81.13 \%)$ & $189(97.93 \%)$ & 28.42 \\
\hline Total & $\mathbf{2 4 6}$ & $\mathbf{5 3}(\mathbf{5 8 . 0 7 \%})$ & $\mathbf{1 9 3}(\mathbf{4 1 . 9 3 \% )}$ & $\mathbf{2 5 . 3 9}$ \\
\hline
\end{tabular}

$\chi^{2}$-Value: 21.85 , P-Value: 0.000

\subsection{Entomological Survey}

A total of $12 \mathrm{NGU}$ traps were deployed in the two peasant associations of Bolosso Bombe woreda. Out of $12 \mathrm{NGU}$ traps deployed, 6 were in Bedaye PAs of Yogo village and the remaining 6 were in the Ossie PAs of Mechancho river gorge. Three genera of biting flies (Glossina, Tabanus and Stomoxys) were caught. The total flies caught were 314 , of which 230 (73.24\%) were Stomoxys, 72 (22.93\%) were Tabanus and $12(3.82 \%)$ were Glossina species (G.pallidipes and G.fucipes). The mean catch of all flies was higher in Yogo village (4.25 flies/trap/day). An overall apparent density of tsetse flies is 0.5 fly per trap per day. The apparent fly density obtained in the study period was 12.75 and 13.42 flies/trap/day in Bedaye and Ossie, respectively as depicted in table (4). 
Prevalence of Bovine Trypanosomosis and its Vectors in Selected Peasant Associations of Boloso Bombe Woreda, Southern Ethiopia

Table4. Apparent fly densities (flies/trap/day) in the two peasant associations of Boloso Bombe Woreda

\begin{tabular}{|c|c|c|c|c|c|c|}
\hline PAs & Village/Site & Altitude (m) & Fly Species & Total & $\mathrm{F} / \mathrm{T} / \mathrm{D}$ & Mean Catch \\
\hline \multirow[t]{3}{*}{ Bedaye } & \multirow[t]{3}{*}{ Yogo } & \multirow[t]{3}{*}{$1334-1385$} & G. pallidipes & 4 & 0.33 & \multirow[t]{3}{*}{$4.25 \mathrm{f} / \mathrm{t} / \mathrm{d}$} \\
\hline & & & Tabanus & 35 & 2.92 & \\
\hline & & & Stomoxys & 114 & 9.5 & \\
\hline \multirow[t]{4}{*}{ Ossie } & \multirow{4}{*}{$\begin{array}{l}\text { Mechancho } \\
\text { river gorge }\end{array}$} & \multirow[t]{4}{*}{$961-1116$} & G.pallidipes & 5 & 0.42 & \multirow[t]{4}{*}{$3.36 \mathrm{f} / \mathrm{t} / \mathrm{d}$} \\
\hline & & & G.fuscipes & 3 & 0.25 & \\
\hline & & & Tabanus & 37 & 3.08 & \\
\hline & & & Stomoxys & 116 & 9.67 & \\
\hline \multicolumn{4}{|c|}{ Total } & 314 & 26.17 & \\
\hline
\end{tabular}

\section{DISCUSSION}

During the present study, an overall prevalence of $5.69 \% \quad(95 \% \quad \mathrm{CI}=27.8-8.60) \quad$ bovine trypanosomosis was recorded. The result of the present study was almost similar with other earlier reports from neighboring woredas. Getnet (2008) reported $5.75 \%$ prevalence of bovine trypanosomosis in Soddo Zuria woreda and Teka et al. (2012) reported a prevalence of $4.43 \%$ in Arba Minch woreda. There were also similar repots from other parts of the country. Belay (2010) reported a prevalence of $3.65 \%$ in around BahirDar, Abebayehu and Biniam (2009) reported a prevalence of $4.4 \%$ at Benchi Maji zone of south Ethiopia and Lema (2009) reported $8.75 \%$ in Konso Special District. In contrast to this, it was lower than the result of Bitew et al. (2011) who reported a prevalence of $11.5 \%$ at Jabi Tehenan district of west Gojjam of Amhara regional state, Mekuria and Gadissa (2011) reported a prevalence of $12.41 \%$ in Metekel and Awi zones of Northwest Ethiopia, Begna et al. (2011) reported a prevalence of $14.2 \%$ at Humbo district of Southern Ethiopia and Endashaw (2010) reported a prevalence of $12 \%$ at Konta special woreda. The reason for these differences might be due to the season during which the survey conducted, differences in application of relatively well designed methods of tsetse control and treatment, expansion of cultivation in the area which indirectly affects flies distribution, expansion of veterinary clinics, and difference on the level of awareness of people towards the control and treatment of the disease.

The present study indicated that there was no significance difference in trypanosome prevalence between the study PAs $(p>0.05)$. However, high prevalence was recorded in Bedaye and Ossie peasant associations because the Yogo village used as grazing and Mechancho River gorge is suitable habitats for the vectors. Statistically significant difference $(\mathrm{p}<0.05)$ was observed in infection rate among poor and good body conditioned animals. This could be attributed, among other factors, as an effect of trypansomosis on the body condition of infected cattle. Animals with poor body condition were more associated with the disease as compared to animals with good body condition. This result was in agreement with that of Teka et al. (2012); Shimelis et al. (2011); Bitew et al. (2010) and Dagnachew et al. (2011). Trypanosomosis cause weight loss (cachexia) and emaciation is the characteristic sign of trypanosomosis (FAO, 2002).

Among the different species of trypanosomes detected in the study period, T.congolense $11(78.56 \%)$ was the most prevalent species followed by T.vivax $3(21.44 \%)$. However, there was no mixed infection in this study. The dominancy of T.congolese in the present study is in concordance with the previous results of Teka et al., (2012) who reported a high proportion of T.congolense in the southern rift valley and Arba Minch woreda, respectively. They reported $70 \%$ and $82.35 \%$ of T.congolense and $20 \%$ and $5.88 \%$ of T.vivax infection, respectively. Slightly less prevalence of T.congolense than the present study was reported by Terzu (2004) in selected sites of southern region (63.4\%); Shimelis et al.(2011) in Assosa district of Benishangul Gumuz Regional State and Dagnachew and Abebe (2007) which is 58\%. The high ratio of T.congolense in tsetse infested area may be ascribed to the more efficient transmission of T.congolese by major cyclical vectors than T.vivax in East Africa (Langrigde, 1976). The predominance of T.congolense infection in cattle may also associated with high number of seroderms of T.congolense as compared to T.vivax by the infected animals (Leak, 1999).

During the study period, the prevalence of bovine trypanosomosis was analyzed between sexes of animals and, among the 14 trypanosome positive animals; 8 (7.69\%) of them were recorded in male and $6(4.23 \%)$ were female animals. There was no significance difference between the prevalence of the 
infection rate and sex of animals but there was high prevalence of trypanosomosis in male than females. This result was in agreement with Daya and Abebe (2008); Teka et al. (2012) and Bitew et al. (2011). Ataro (2011) associated the possible reason for relative increment of prevalence in male animals to the fact these animals used as draught purpose and travel long distance in the areas where tsetse challenge is present and as a result, the risk of contracting trypanosomosis is also very high.

There was no statistically significance $(\mathrm{p}>0.05)$ difference between prevalence of trypanosomosis in the two age groups. The prevalence of infection was found to be $5.88 \%$ in the young and $5.99 \%$ in the adult age group animals. There was slightly higher infection in adult age groups. This result is in agreement with that of Bitew et al. (2010) and Teka et al. (2012).

During the study period, cattle with $\mathrm{PCV} \leq 24$ were considered as anemic (Van den Bossche et al., 2000) which is said to be the principal sign of trypanosomosis in the livestock. The mean PCV-value for the parasitemic cattle was $22.36 \%$ which fall in the range of anemia while the mean PCV value of the apparasitemic cattle was $28.42 \%$. Moreover, trypanosome infection and mean PCV-values obtained in the study of parasitemic and apparasitemic cattle were in agreement with the report of Bitew et al. (2010); Sinishaw (2004) and Dagnachew et al. (2011). Trypanosome infected cattle were observed to have low PCV values (anemic) compared to uninfected animals. The study indicated that some of the animals with PCV value in the normal range were also trypanosome positive. The study indicated that $2.07 \%$ of cattle have a $\mathrm{PCV}$ value in the normal range $(\mathrm{PCV}>24)$ but they react positively to trypanosomosis infection and this may have occurred due to recent infection of trypanosmosis. This result is in agreement with the previous results of Kebede and Animut (2009) and Teka et al. (2012) who found cattle having PCV value of normal range were shown to be infected with trypanosome parasite. Other than this, it can be assumed that, numerous concurrent diseases like helmenthiasis, tick-borne diseases and nutritional imbalance can cause anemia in both trypanosome positive and negative animals (Dagnachew et al., 2011).

Findings of the fly survey in this study could be considered as a preliminary work. In Ethiopia, though there has not been a specific study on biting flies in alienation from the usual tsetse fly studies, few authors have reported the name of some biting flies as Tabanidae and Stomoxyinae at a family level (Kidane-Mariam, 2000). On the present entomolgical survey; G.pallidipes and G.fuscipes were detected though relatively in very small number compared to other mechanical vectors which were also identified in relatively higher number. The mean catch of all flies in the Yogo village were higher (4.25 flies/trap/day). The study also indicated that an overall apparent tsetse fly density of 0.5 flies/trap/day. This result was in disagreement with the study of Teka et al. (2012) which reported about 14.97 flies/trap/day for all flies, and the apparent tsetse fly density obtained was 0.33 and $0.67 \mathrm{flies} / \mathrm{trap} /$ day in Yogo village and Mechancho river gorge, respectively and this was also disagreed with the report of Mekuria and Gadissa (2007) that they reported the overall apparent density of tsetse and other biting flies of 6.49 and 0.65 flies/trap/day, respectively. Generally, the present study showed that both the prevalence of trypanosomosis and the flies caught were very low. Prevalence of the disease is low due to intensive use of trypanocidal drugs as curative and preventive doses has suppressed the disease prevalence in the study area and other pilot control interventions like application of insecticides to live animals (spot-on) and the use of insecticide-impregnated targets to suppress the population of insect vectors. The survey period was the hot season in that high temperature increase trypanosome infectivity and shortens their development cycle; unfavorable for tsetse flies whose population becomes smaller, younger, and more localized. Thus, tsetse population decreases during dry seasons according to Sinishaw et al. (2006).

\section{CONCLUSION AND RECOMMENDATIONS}

The study revealed that trypanosomosis is one of the major impediments to livestock development and agricultural production in the study area, contributing negatively to the overall development in general and to food self-reliance in particular. The most prevalent trpanosome species in the area was T.congolense followed by T.vivax. Infection with trypanosomosis negatively affected PCV and body conditions. During entomological survey, two species of tsetse flies (G.pallidipes and G.fuscipes) and 
Prevalence of Bovine Trypanosomosis and its Vectors in Selected Peasant Associations of Boloso Bombe Woreda, Southern Ethiopia

other biting flies (Tabanus and Stomoxys) were also identified.

Based on the above conclusion, the following recommendations are forwarded:

Strategic control of trypanosomosis and integrated vector control should be strengthened to improve livestock production and agricultural development in the area.

$>$ Suitable community based tsetse and trypanosomosis control program should be designed and implemented

$>$ Attempt should be made to expand government and private veterinary services to serve the community properly.

$>$ Further surveys and studies should be conducted in order to find out appropriate, feasible control methods of trypanosomosis and/or vectors in the study area.

\section{ACKNOWLEDGEMENTS}

It is not an easy task to write this paper only with the efforts of mine, thanks to Almighty God. I would like to express my deep, sincere appreciation and thanks to my advisor Dr. Zerihun Hailemariam for his constructive and valuable comments on reviewing, improving and professional assistant on this paper. It also extends my deep sense of gratitude and my heartfelt thanks to Tekle Alaro and Mamecha Mena for their cooperation during this research.

Words cannot express my heartily and profoundly indebtedness to my dear parents, especially my mother Liya Kora and Yacob Desalegn for their incalculable and unreserved financial support throughout my long term study and relatives who brought me up with the best character and supports memorably, revocation, and finance and material from my birth day to this remarkable stage. I also appreciate the encouragement I had from my dear brothers and sisters.

I would like to appreciate the cooperation of Wolaita Soddo Regional Veterinary Laboratory staffs for their logistic and technical inputs.

Last but not certainly the least, special thanks goes to my classmates and best friend especially Endashawu Esayas for his idea sharing.

ARC Journal of Animal and Veterinary Sciences

\section{REFERENCES}

[1] Abebayehu, T. and Biniam, T. (2010). Bovine trypanosomsis and its vectors in the two villages of Benchi Maji Zone, Southwestern Ethiopia. Trop.Anim.Health.Prod. 42 (8): 17571762.

[2] Abebe, G. (2005). Review Article: Trypanosomosis in Ethiopia, Addis Ababa University, Faculty of Veterinary Medicine, DebreZeit. Ethip.J.Biol.Sci. 4 (1): 75-121.

[3] Abebe, G. and Jobere, Y. (1996). Trypanosomiasis: A threat to cattle production in Ethiopia. Revue. Med. Vet. 147: 897-902.

[4] Ataro, A. (2011): Prevalence of bovine trypanosomosis in selected settlements areas of Konta Special Woreda of Southern Nation, Nationalities and Peoples Regional States (SNNPRS). DVM Thesis, Haramaya Univerisity, College of Veterinary Medicine, Haramaya, Ethiopia. Pp. 1-24.

[5] Belay, S. (2010). A study on Prevalence of Bovine Trypanosomosis in some selected areas of South Achefer District around BahirDar. DVM Thesis, Haramaya Univerisity, College of Veterinary Medicine, Haramaya, Ethiopia. Pp. $1-24$.

[6] Bitew, M., Amedie,Y., Abebe, A. and Tolosa, T. (2011): Prevalence of Bovine Trypanosomosis in selected areas of Jabi Tehenan Districts, West Gojjam of Amhara Regional State, Northwestern Ethiopia. Afr. J. Agric. Res. 6 (1):140-144.

[7] Bombe WOA. (2010). Bolosso Bombe Woreda of Agriculture.

[8] Chernet, T., Sami, R.A., Speybroeck, N., Panadam, J. M., Nadzr, S. and Van den Bossche, P. (2006): A comparative longititudinal study of bovine trypanosomosis in tsetse-free and tsetse- infested zones of Amhara Region, Northwest Ethiopia. Vet. Parasitol. 88:163-176.

[9] Cynthia, M.K. (2005). The Merck Veterinary Manual. $9^{\text {th }}$ ed, Published by Merial and CO.INC. White house station N.J., USA. Pp. 32-34

[10] Dagnachew, S. and Abebe, G., 2007. Studies on tsetse-transmitted trypanosomosis in new settlement areas of Jawi and Quara districts of Amhara region, Northwest Ethiopia. In proceedings of the $29^{\text {th }}$ meeting of the International Scientific Council for Trypanosomosis Research and Control (ISCTRC), Luanda, Angola, $1^{\text {st }}-5^{\text {th }}$ October, 2007.

[11] Dagnachew, S., Girma, H. and Abebe, G. (2011): A cross-sectional study on bovine trypanosomosis in Jawi district of Amhara Region, Northwest Ethiopia. Ethiop. Vet. J. 15 (1):69-78. 
[12] Daya, T. and Abebe, G., (2008). Seasonal Dynamics of Tsetse and Trypanosomosis in selected sites of Southern Nation, Nationalities and Peoples regional State, Ethiopia. Ethiop. Vet. J. 12 (2): 77-92.

[13] Dwight, D. (2003). Georgis Parasitology for Veterinarians. $8^{\text {th }}$ edition. Elsevier, USA. PP. 83.

[14] Endashaw, R. (2010): Identification of Tsetse and Bovine Trypanosomosis in selected sites of Konta Special woreda, SNNPRS. DVM Thesis, Haramaya University, College of Veterinary Medicine, Haramaya, Ethiopia. Pp. 1-26.

[15] FAO. (2002). Food, agriculture and food security: The global dimension.

[16] Getnet, B. (2008). Prevalence of Bovine Trypanosomosis in the Soddo Zuria Woreda of Wolaita Zone, SNNPRS. DVM Thesis. Haramaya University, College of Veterinary Medicine, Haramaya, Ethiopia. Pp. 1-22.

[17] Itard, J. (1992). African Animal Trypanosomiasis. Manual of Tropical Veterinary Parasitology. CAB international, UK.

[18] Kebede, N. and Animut, A. (2009): Trypanosomosis of cattle in selected districts of Awi Zone, Northwestern Ethiopia. Trop. Animal. Health. 41:1353-1356.

[19] Kidane-Mariam, A., 2000. Study of Trypanosomosis and its vectors in Humbo and Merab Abaya woredas. J. Ethiop. Vet. Assoc. 5(1):61-77.

[20] Langridge, W.P (1976): A tsetse and trypanosomosis survey of Ethiopia. London: Ministry of Overseas Development of British and Ministry of Agriculture of Ethiopia. P. 96 -98 .

[21] Leak, S.G.A. (1999). Tsetse Biology and Ecology: Their role in the Epidemiology and Control of Trypanosomiasis. CAB International, Nairobi, Kenya. Wallingford (UK). Pp. 568.

[22] Lema, D. (2009). Identification of Tsetse and Bovine Trypanosomosis in selected peasant associations of Amaro and Konso Special District, SNNPR. DVM Thesis. Haramaya University, College of Veterinary Medicine, Haramaya, Ethiopia. Pp. 1-26.

[23] Maclennan, K.J.R. (1980). Tsetse transmitted trypanosomiasis in relation to the rural economy in Africa. Part one. Tsetse infection world animal review. 36: 2-17.

[24] Mekuria, S. and Gadissa, F. (2011): Survey on bovine trypanosomosis and its vectors in Metekel and Awi Zones of Northwest, Ethiopia. Acta Tropica, 117:146-151.

[25] MoARD. (2004). Ministry of Agriculture and Rural Development of the Government of
Ethiopia: Tsetse and Trypanosomosis Prevention and Control Strategies. Amharic Version. October 2004. (Tikimt, 1997 Ethiop. Cal.). Paper presented on Farming Tsetse Controlled Areas (FITA), Ethiopia. Final Work Shop, December, 27-28. Adama, Ethiopia. Unpublished Workshop Proceedings.

[26] Murray, N., Murran, P. K., and McIntyre, W. I. M. (1977): An Improved Parasitological Diagnosis of African Trypanosomosis. Trans. R. Soc. Trop. Med. Hyg. 71:325-326.

[27] Nicholson, M.J. and Butterworth, M.H. (1986). A Guide to body condition scoring of zebu cattle. ILCA, Addis Ababa, Ethiopia.

[28] Paris, J., Murray, M. and Agure, R. (1979). Report of the expert consultation on the research of Trypanosomosis, FAO, Rome.

[29] Paris, J., Murray, M. and Mcodimba, F. (1982). A comparative evaluation of the parasitological technique currently available for the diagnosis of African Trypanosomosis in cattle. Acta. Trop. 39:1-11.

[30] Radostitis, O.M., Gray, C. and Blood, D.C. (2007). Veterinary Medicine: Textbook of disease of cattle, sheep, goats, pigs and horses. $10^{\text {th }}$ ed. Elsevier, London. Pp 1531-1540.

[31] Seifert, H.S.H. (1996). Tropical animal health. $2^{\text {nd }}$ edition. Dodrech, Kluwer Academic publisher. Pp. 78-170.

[32] Shimelis, D., Habtamu, G. and Getachew, A. (2011). A cross-sectional study on bovine trypanosomosis in Jawi District of Amhara Region, Northwest Ethiopia. Ethiop. Vet. J. 15(1): 69-78.

[33] Shimelis, M., Mekonnen, A. and Abebe, F. (2011): Study on the Prevalence of Major Trypanosomes Affecting Bovine in Tsetse Infested Assosa District of Benishangul Gumuz Regional State, Western Ethiopia. Global Veterinaria 7(4): 330-336.

[34] Sinishaw, A., Abebe, G., Desquesnes, M.and Yoni, W. (2006): Biting flies and T. vivax infection in three highland districts bordering lake Tana, Ethiopia. Vet. Parasitol. 142:35-36.

[35] Sinishaw, A. (2004): Prevalence of trypanosomosis of cattle in three woredas of Amhara Region. MSc thesis, Faculty of Veterinary Medicine, Addis Ababa University, DebreZeit, Ethiopia. Pp.1-56.

[36] Smith, B.P. (2009). Large Animal Internal Medicine. $4^{\text {th }}$ ed. Elsevier. Pp. 1160.

[37] SRVL. (2004). Annual report of Veterinary Laboratory: Wolaita Soddo Ethiopia.

[38] SRVL. (2006). Wolaita Soddo Regional Veterinary Laboratory.

[39] STATA-9.1984- 2009. Stata corp.4905 Lake way Drive College Station, Texas 77845 USA. 
Prevalence of Bovine Trypanosomosis and its Vectors in Selected Peasant Associations of Boloso Bombe Woreda, Southern Ethiopia

[40] Taylor, M.A., Coop, R.L. and Well, R.L. (2007). Veterinary Parasitology. $3^{\text {rd }}$ ed. Pp. 4243.

[41] Teka, W., Terefe, D. and Wondimu, A.(2012): Prevalence Study of Bovine Trypanosomosis and Tsetse density in selected villages of Arba Minch, Ethipiopia. J. Vet. Med. Anim. Hlth. 4 (3):36-41.

[42] Terzu, D. (2004). Seasonal Dynamics of Tsetse and Trypanosomsis in selected sites of Southern Nation, Nationalities and Peoples Regional State (SNNPRS), MSc thesis, Addis
Ababa University, Faculty of Veterinary Medicine, DebreZeit, Ethiopia. p. 1-80.

[43] Thrustfield, M. (2005). Veterinary Epidemiolgy. $3^{\text {rd }}$ edition. UK, Blackwell Science Ltd. Pp. 233-250.

[44] Urquhart, G.M., Armour, G., Duncan, J.L., Dunne, A.M. and Jennings, F.W. (1996). Veterinary Parasitology. $2^{\text {nd }}$ ed. Blackwell Science, London, UK. Pp. 212-219.

[45] Van den Bossche, P., Shumba, W. and Makhambera, P., (2000). The Distribution and Epidemiology of bovine trypanosomiasis in Malawi. Vet. Parasitol. 88:163-176.

\section{ANNEXES}

Annex1. Body condition scoring in cattle

\begin{tabular}{|c|l|c|}
\hline Score & Description & Grouping \\
\hline 0 & $\begin{array}{l}\text { Emaciated animals with an apparent fat, subcutaneous fat covering spinous process in } \\
\text { lumbar region feels sharp }\end{array}$ & \multirow{2}{*}{ Poor } \\
\hline 1 & $\begin{array}{l}\text { Spinous process is sharp but less than in score'0'. There is some subcutaneous fat on the } \\
\text { process and points of hip. }\end{array}$ & \multirow{2}{*}{ Good } \\
\hline 2 & Individual spinous process is fairly sharp to touch and ribs can be seen individually & \\
\hline 3 & Spinous can be felt but rounded feel and individual can be seen. & \\
\hline 5 & fat and rounded. & Spinous cannot be felt even with firm pressure and there has block appearance. \\
\hline
\end{tabular}

Source: Nicholson and Butterworth, 1986

Annex2. NGU traps deployed in YOGO village of Bedaye PA

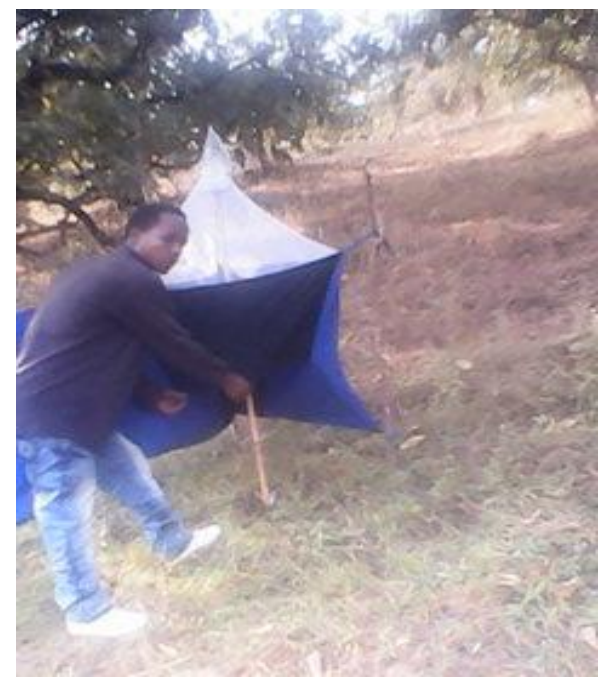

Citation: Wondimu Wodajo. Prevalence of Bovine Trypanosomosis and its Vectors in Selected Peasant Associations of Boloso Bombe Woreda, Southern Ethiopia. ARC Journal of Animal and Veterinary Sciences. 2019; 5(2):25-34. doi: dx.doi.org/10.20431/2455-2518.0502004.

Copyright: (C) 2019 Authors. This is an open-access article distributed under the terms of the Creative Commons Attribution License, which permits unrestricted use, distribution, and reproduction in any medium, provided the original author and source are credited. 